\title{
Physicochemical properties, bioactive composition and antioxidant activities of noni fruit juices from different regions of cultivation
}

\author{
$\mathrm{Ja}$ Min $\mathrm{Kim}^{1,2}$, Yong Jun $\mathrm{Jo}^{3}$, Dongyup $\mathrm{Hahn}^{1,2 *}$ \\ ${ }^{1}$ School of Food Science and Biotechnology, Kyungpook National University, Daegu 41566, Korea \\ ${ }^{2}$ Institute of Agricultural Science and Technology, Kyungpook National University, Daegu 41566, Korea \\ ${ }^{3}$ New Technology and Innovation Department, Nutribiotech, Seoul 06132, Korea
}

\section{재배지에 따른 노니열매 착즙액의 이화학적 특성, 생리활성 성분 및 항산화 활성}

\author{
김자민 ${ }^{1,2} \cdot$ 조용준 $^{3} \cdot$ 한동엽 $^{1,2 *}$ \\ ${ }^{1}$ 경북대학교 식품공학부, ${ }^{2}$ 경북대학교 농업과학기술연구소, ${ }^{3}$ 뉴트리바이오텍
}

\begin{abstract}
The objectives of this study were to compare the physicochemical properties, functional components and antioxidant activities of noni fruit juices from six different regions of cultivation: Samoa, Indonesia, China (Hainan), Hawaii, Thailand and Tahiti. The $\mathrm{pH}$ values of noni fruit juices ranged from 3.63 to 3.83, and the soluble contents were 5.97-6.97 ${ }^{\circ}$ Brix. In regard to color, the $L$, a and $b$ values of noni juices were in the ranges of 33.41-46.51, 3.44-7.98, and 2.42-22.20, respectively. The polyphenol content of noni fruit juice from Indonesia was significantly higher than other samples. The Thailand noni fruit juice contained the highest amounts of scopoletin $(8.62 \mathrm{mg} / 100 \mathrm{~mL})$ and rutin $(2.03 \mathrm{mg} / 100 \mathrm{~mL})$. The noni fruit juice from Indonesia showed the higher antioxidant activities (DPPH and ABTS radical scavenging activity) than others. In conclusion, These results suggest that noni fruit juice may be a good source of functional food with antioxidant activity and can serve as the basis data for the use of noni fruit in the food industry.
\end{abstract}

Key words : noni fruit, antioxidant activity, scopoletin, rutin, Morinda citrifolia L.

\section{서 론}

Morinda citrifolia L.는 꼭두서니과에 속하는 다년생 식물 로 흔히 노니(noni)라고 불리나 지역에 따라 indian mulberry, nonu, nono, ach, mengkudu, nhau, painkiller bush 및 cheese fruit 등으로 다양하게 불려진다. 노니는 폴리네시아인들에 게는 2,000년 이상 질병치료를 위한 민간요법제로 사용되 었으며 최근 유럽식품안전국에서 novel food로 선정되면서 건강기능식품으로 각광받고 있다(1). 노니에는 영양성분을

*Corresponding author. E-mail : dohahn@knu.ac.kr Phone : 82-53-950-5756, Fax : 82-53-950-6750

Received 30 October 2017; Revised 15 November 2017; Accepted 16 November 2017.

Copyright (c) The Korean Society of Food Preservation. All rights reserved.
포함한 약 200 여종 이상의 다양한 성분들이 함유되어있으 며, 노니에 함유된 주요 성분 중 스코폴레틴(scopoletin)은 쿠마린(coumarin) 계열 화합물로서, 주름개선 효과, 세로토 닌(serotonin) 분비 조절, 혈당강하, 항산화 및 항고혈압 등 에 효과적으로 알려져 있다(2-5). 뿐만 아니라 노니에는 루 틴(rutin), 우르솔산(ursolic acid), 프로제로닌(proxeronine), 담나칸탈(damnacanthal) 및 안트라퀴논(anthraquinone) 등 이 다량 함유되어 있으며, 이러한 성분들은 항균, 항바이러 스, 항고혈압, 항염증 및 항산화 효과 등 다양한 생리활성과 관련되어있다(6-10).

노니는 잎, 뿌리, 줄기, 씨, 꽃, 열매 등 어느 부분을 막론하 고 약효가 뛰어나다고 알려져 있으며 특히 열매는 소염진 통, 혈당억제, 변비해소, 지혈, 염증해소 등 모든 효능에 탁월한 것으로 알려져 있다(11). 감자크기 정도로 잘 익은 성숙열매는 황백색으로 다량의 과즙을 포함하며, 열매로부 
터 착즙한 과즙은 영양성분이 풍부하고 비타민, 미네랄 또 한 균형적으로 함유되어 있다. 노니 열매 착즙액의 superoxide anion radical 소거능은 비타민 $\mathrm{C}$ 보다 2.8 배, 피크노제놀 (pycnogenol)보다 1.4배 강하다고 밝혀졌으며(10), 이러한 항산화 능력은 암세포 성장률과 확산을 줄여주고 암세포 혈관 퇴화 등의 다른 생리활성 기전에도 관여한다고 알려져 있다(12). 이처럼 노니의 다양한 생리활성이 알려지면서 1996년 Tahitian noni juice의 출시를 시작으로 미국, 중국을 비롯한 여러 나라에서 열매를 액기스로 추출하여 쥬스 혹은 분말 및 젤리 타입의 건강기능식품으로 판매하기 시작하였 으며, 국내에도 수입되어 많은 사람들이 다양한 형태로 섭 취하고 있는 추세이다 $(6,13)$.

노니는 동남아시아가 원산지이며 현재는 호주, 중남미, 인도, 태평양도서지역 등지에서 널리 재배되고 있으며, 재 배된 지역마다 기후와 토양 등과 같은 환경적 조건에 따른 노니 열매의 품질의 차이가 있다(13). 국내외 노니에 관한 연구동향을 살펴보면 노니와 관련한 다양한 생리활성에 대한 연구들은 활발히 진행되고 있으나, 재배지역에 따른 노니의 이화학적 특성 및 기능적 특성 비교에 대한 연구는 체계적으로 이루어지지 않고 있으며 이를 이용한 다양한 제품개발의 기초자료 또한 부족한 실정이다.

따라서 본 연구에서는 사모아, 인도네시아, 중국 하이난, 하와이, 태국 및 타히티에서 재배한 노니 열매를 착즙한 착즙액의 이화학적 특성, 생리활성물질 및 항산화 활성을 비교분석함으로써 향후 노니의 활용확대를 위한 기초자료 를 제공하고자 한다.

\section{재료 및 방법}

\section{실험재료}

본 실험에서는 사모아(Samoa), 인도네시아(Indonesia), 중국 하이난(China), 하와이(Hawaii), 태국(Thailand), 타히 티(Tahiti)에서 재배된 노니 열매를 착즙한 노니 착즙액을 (주)뉴트리바이오텍에서 제공받아 $4{ }^{\circ} \mathrm{C}$ 이하에 냉장보관하면 서 실험에 사용하였다.

\section{$\mathrm{pH}$, 가용성 고형분 및 색도 측정}

$\mathrm{pH}$ 는 $\mathrm{pH}$ meter(GmbH; 8603, Mettler-Toledo, Greifensee, Switzerland)로 측정하였고, 가용성 고형분 함량은 refractometer (N-1a, Atago Co., Tokyo, Japan)를 사용하여 측정하였다. 원산지별 노니 착즙액의 색도는 표준백색판 $\left(\mathrm{L}^{*}=97.79\right.$, $\left.\mathrm{a}^{*}=-0.38, \mathrm{~b}^{*}=2.05\right)$ 으로 보정한 colorimeter(CR-400, Minolta Co., Tokyo, Japan)를 이용하여 hunter값 $\left(\mathrm{L}^{*}=\right.$ lightness, $\mathrm{a}^{*}=$ redness, $\mathrm{b}^{*}=$ yellowness)을 5 회 반복 측정한 평균값을 나타내었다.

\section{총 폴리페놀 함량 측정}

총 폴리페놀 함량은 Folin-Denis법(14)을 변형하여 측정 하였다. 즉, 원산지별 노니 시료 $0.1 \mathrm{~mL}$ 를 시험관에 취한 후 Folin-Ciocalteu's phenol reagent $0.1 \mathrm{~mL}$ 를 첨가하여 잘 혼합한 후 실온에서 3 분간 방치하였다. 3 분 후 $10 \% \mathrm{Na}_{2} \mathrm{CO}_{3}$ $0.2 \mathrm{~mL}$ 가하여 혼합하고 증류수 $2 \mathrm{~mL}$ 를 첨가하여 실온의 암실에서 1시간 방치한 후 microplate reader(Infinite F200, Tecan, Grödig, Austria)를 사용하여 $725 \mathrm{~nm}$ 에서 흡광도를 측정하였다. 총 페놀 화합물의 표준물질로 tannic acid (Sigma-Aldrich, St. Louis, MO, USA)을 이용하여 작성한 표준곡선으로부터 함량을 계산하였다.

\section{$\mathrm{DPPH}$ 라디칼 소거능 측정}

1,1-diphenyl-2-picryl-hydrazyl(DPPH) 라디칼 소거능은 Blois(15)의 방법을 변형하여 측정하였다. 샘플 $0.1 \mathrm{~mL}$ 를 취하여 $0.2 \mathrm{mM} \mathrm{DPPH}$ 용액 $50 \mu \mathrm{L}$ 를 가한 후 $37^{\circ} \mathrm{C}$ 에서 30 분 간 반응시킨 후 microplate reader(Surise, Tecan)를 사용하여 $517 \mathrm{~nm}$ 에서 흡광도를 측정하였다.

\section{ABTS 라디칼 소거능 측정}

2,2'-Azino-bis(3-ethylbenzothiazoline-6-sulfonic acid) (ABTS) 라디칼 소거능은 $\operatorname{Re}$ 등(16)의 방법을 변형하여 실 험하였다. $7 \mathrm{mM} \mathrm{ABTS}$ 와 $2.45 \mathrm{mM}$ potassium persulfate를 증류수에 용해하여 암소에서 15-16시간 동안 방치하여 ABTS cation radical $\left(\mathrm{ABTS}^{-1}\right)$ 을 형성시킨 후, 이 용액을 734 $\mathrm{nm}$ 에서 흡광도 값이 $0.600 \pm 0.002$ 가 되도록 에탄올로 희석 하였다. 희석된 $\mathrm{ABTS}^{+}$용액 $50 \mu \mathrm{L}$ 에 샘플용액 $50 \mu \mathrm{L}$ 를 가하여 6분간 반응시킨 후, microplate reader(Infinite F200, Tecan)을 사용하여 $734 \mathrm{~nm}$ 에서 흡광도를 측정하였다.

\section{스코폴레틴 및 루틴 함량 분석}

스코폴레틴 및 루틴 함량을 분석하기 위하여 UHPLC (Nexera XR, Shimadzu Co., Kyoto, Japan)를 이용하여 분석 하였으며, 원산지별 노니 열매 착즙액을 $0.45 \mu \mathrm{m}$ membrane filter(Milipore Co., Billeria, MA, USA)로 여과하여 측정시 료로 사용하였다. Column은 $\mathrm{C}_{18}$ column(HECTOR-M C18, RStech Co., Daejeon, Korea)을 사용하였으며, 온도는 $39^{\circ} \mathrm{C}$, 검출 파장은 $345 \mathrm{~nm}$ (스코폴레틴), $354 \mathrm{~nm}$ (루틴)에서 각각 검출하였다. 분석의 이동상 용매로는 $0.1 \%$ trifluoroacetic acid in distilled water와 $100 \%$ acetonitrile을 사용하였고, 분석시간에 따라 이동상의 조성을 변경하였다. 이동상의 유속은 $0.8 \mathrm{~mL} / \mathrm{min}$, 시료 주입량은 $10 \mu \mathrm{L}$, 스코폴레틴 및 루틴 표준품은 Sigma-Aldrich로부터 구입하였다.

\section{통계처리}

본 실험결과의 통계분석은 $\operatorname{SPSS}(23$, Chicago, IL, USA) 통계 프로그램을 이용하여 각 시료군 간의 유의적인 차이를 
one-way ANOVA로 분석하여 Duncan's multiple range test 를 실시하여 분석하였다.

\section{결과 및 고찰}

\section{산지별 노니열매 착즙액의 이화학적 특성}

산지별 노니열매 착즙액의 $\mathrm{pH}$, 가용성 고형분 함량 및 색도를 측정한 결과는 Table 1 과 같다. 신맛과 관련이 있는 $\mathrm{pH}$ 를 측정한 결과, 사모아, 인도네시아, 중국, 하와이, 태국, 타히티에서 재배된 노니열매의 착즙액의 $\mathrm{pH}$ 는 $3.75,3.79$, $3.83,3.63,3.81,3.64$ 로 각각 측정되었으며, 이 중 중국산이 $\mathrm{pH} 3.83$ 으로 가장 높은 $\mathrm{pH}$ 값을 나타내었으며, 하와이산이 $\mathrm{pH} 3.63$ 으로 가장 낮은 $\mathrm{pH}$ 값을 나타내었다. 코스타리카산 노니열매 주스의 $\mathrm{pH}$ 는 3.4로 측정되었고(17), 멕시코산 노 니열매 주스의 $\mathrm{pH}$ 는 3.16 로 측정되어(7), 본 연구 결과와 유사하였다. 뿐만 아니라 $\operatorname{Kim}(18)$ 은 노니 원액에 물, 홍삼, 복분자 및 석류를 첨가하여 음료를 개발하여 $\mathrm{pH}$ 를 측정하 였으며, 그 결과 3.27-3.47로 본 연구결과와 유사한 경향을 나타내었다.

산지별 노니열매 착즙액의 가용성 고형분 함량은 5.97-6.97 ${ }^{\circ} \mathrm{Brix}$ 범위로 하와이산이 $6.97{ }^{\circ} \mathrm{Brix}$ 로 가장 높은 고형분 함량을 보였으며, 반면 인도네시아산이 $5.97{ }^{\circ} \mathrm{Brix}$ 로 가장 낮은 고형분 함량을 보였다. $\mathrm{Kim}(18)$ 이 분석한 $100 \%$ 노니 열매 원액의 고형분 함량은 $8.87{ }^{\circ} \mathrm{Brix}$ 로 측정되 어, 본 연구에 사용된 산지별 노니 열매 착즙액과 다소 차이 를 보였다.

산지에 따른 노니열매 착즙액의 색도를 측정한 결과, $\mathrm{L}$ 값은 33.41-49.12, a 값은 3.44-7.98, b 값은 2.42-22.20 범위 를 나타내었다. 노니의 과숙한 열매는 일반적으로 대게 황 백색을 나타내나 수확 후 수일 이내로 갈변하여 어두운 황갈색을 나타내며 이러한 열매의 착즙액 색도 역시 어두운 갈색을 띠었다. 색도 중 $\mathrm{L}$ 값은 사모아산, 인도네시아산, 중국산, 하와이산, 태국산, 타히티산 각각 46.04, 36.00, $39.50,46.51,33.41,49.12$ 로 태국산이 유의적으로 가장 낮
은 값을 보였으며, 육안으로도 다른 시료보다 진한 색을 나타내는 것을 확인할 수 있었다. 적색도를 나타내는 a 값은 중국산이 유의적으로 가장 높은 값(7.98)을 나타내었으며, 태국산 노니열매 착즙액이 유의적으로 가장 낮은 값(3.44) 을 나타내었다. 황색도를 나타내는 b 값은 태국산이 2.42의 값으로 유의적으로 가장 낮은 값을 나타내었으며, 시료들 간의 값 차이가 크게 나타났다. 결과적으로 6가지 산지 중 태국산이 $\mathrm{L}, \mathrm{a}$ 및 $\mathrm{b}$ 값이 모두 유의적으로 낮은 값을 보였다. 색도는 기호적 품질 요소로 작용할 뿐만 아니라 색소 성분 의 함량의 차이가 다른 건강기능성과도 관련이 크다고 알려 있으므로(19), 산지별 노니열매 착즙액의 색도차이를 고려 해볼 때 산지에 따른 생리활성물질 및 항산화 활성도 차이 가 있을 것으로 판단된다.

\section{산지별 노니 열매 착즙액의 총 폴리페놀 함량}

식물계에 널리 분포되어있는 폴리페놀 화합물은 항산화 력을 결정짓는 중요한 인자로써 폴리페놀 화합물 구조 내에 존재하는 phenolic hydroxyl기가 수소공여와 페놀 고리구조 의 공명안정화를 통해 항산화력을 발현시킨다(20). 노니에서 발견되는 생리활성물질 중 대부분은 gentisic, p-hydroxybenoic acid 및 chlorogenic acid 등을 포함한 페놀성 물질로 알려져 있으므로 $(10,21)$, 노니 열매 착즙액의 폴리페놀 함량을 측 정하여 항산화능을 예측하고자 하였다. 산지별 노니 열매 착즙액의 총 폴리페놀 함량은 tannic acid로 환산하여 Fig. 1 과 같이 나타내었다. 인도네시아산이 $1.67 \mathrm{mg} / \mathrm{mL}$ 의 폴리 페놀을 함유하고 있으며, 이는 다른 시료와 비교하여 볼 때 유의적으로 높은 함량을 나타내었다. 하와이산과 태국 산은 각각 $1.2 \mathrm{mg} / \mathrm{mL}, 1.21 \mathrm{mg} / \mathrm{mL}$ 로 유의적인 차이가 없었 으며, 중국산 $0.99 \mathrm{mg} / \mathrm{mL}$, 사모아산 $0.84 \mathrm{mg} / \mathrm{mL}$, 타히티산 $0.76 \mathrm{mg} / \mathrm{mL}$ 의 순으로 나타났다. Lin 등(21)은 HPLC를 이용 하여 대만산 노니주스의 페놀물질 7종의 함량을 측정하였 으며, 그 결과 총 $59.41 \mathrm{mg} / 100 \mathrm{~mL}$ 로 본 연구에 사용된 6 가지 산지별 노니 열매 착즙액보다 다소 낮은 총 폴리페놀 함량을 나타내었다. 뿐만 아니라 비트즙을 첨가한 당근주 스의 폴리페놀 함량을 측정한 결과, $54.95-114.27 \mu \mathrm{g} / \mathrm{mL}$ 로

Table 1. pH value, solid content and color difference of noni juices from different regions of cultivation

\begin{tabular}{cccccc}
\hline \multirow{2}{*}{ Sample } & pH value & \multirow{2}{*}{ Brix } & \multicolumn{3}{c}{ Color value } \\
\cline { 4 - 6 } & & & L value & a value & b value \\
\hline Samoa & $3.75 \pm 0.00^{1)(2)}$ & $6.93 \pm 0.06^{\mathrm{a}}$ & $46.04 \pm 0.08^{\mathrm{c}}$ & $5.82 \pm 0.03^{\mathrm{d}}$ & $15.82 \pm 0.03^{\mathrm{c}}$ \\
Indonesia & $3.79 \pm 0.01^{\mathrm{c}}$ & $5.97 \pm 0.06^{\mathrm{c}}$ & $36.00 \pm 0.04^{\mathrm{e}}$ & $6.02 \pm 0.01^{\mathrm{c}}$ & $6.26 \pm 0.02^{\mathrm{e}}$ \\
China & $3.83 \pm 0.00^{\mathrm{a}}$ & $6.17 \pm 0.06^{\mathrm{b}}$ & $39.50 \pm 0.03^{\mathrm{d}}$ & $7.98 \pm 0.05^{\mathrm{a}}$ & $11.50 \pm 0.01^{\mathrm{d}}$ \\
Hawaii & $3.63 \pm 0.00^{\mathrm{e}}$ & $6.97 \pm 0.06^{\mathrm{a}}$ & $46.51 \pm 0.02^{\mathrm{b}}$ & $6.75 \pm 0.03^{\mathrm{b}}$ & $20.32 \pm 0.07^{\mathrm{b}}$ \\
Thailand & $3.81 \pm 0.00^{\mathrm{b}}$ & $6.17 \pm 0.06^{\mathrm{b}}$ & $33.41 \pm 0.01^{\mathrm{f}}$ & $3.44 \pm 0.03^{\mathrm{f}}$ & $2.42 \pm 0.03^{\mathrm{f}}$ \\
Tahiti & $3.64 \pm 0.00^{\mathrm{e}}$ & $6.07 \pm 0.06^{\mathrm{b}}$ & $49.12 \pm 0.01^{\mathrm{a}}$ & $4.80 \pm 0.01^{\mathrm{e}}$ & $22.20 \pm 0.04^{\mathrm{a}}$ \\
\hline
\end{tabular}

\footnotetext{
${ }^{1)} \mathrm{Each} \mathrm{pH}$ and ${ }^{\circ}$ Brix value represents the mean $\pm \mathrm{SD}(\mathrm{n}=3)$. Each color value represents the mean $\pm \mathrm{SD} \quad(\mathrm{n}=5)$.
}

${ }^{2)}$ Values in the column with different superscript letters are significantly different at $\mathrm{p}<0.05$. 


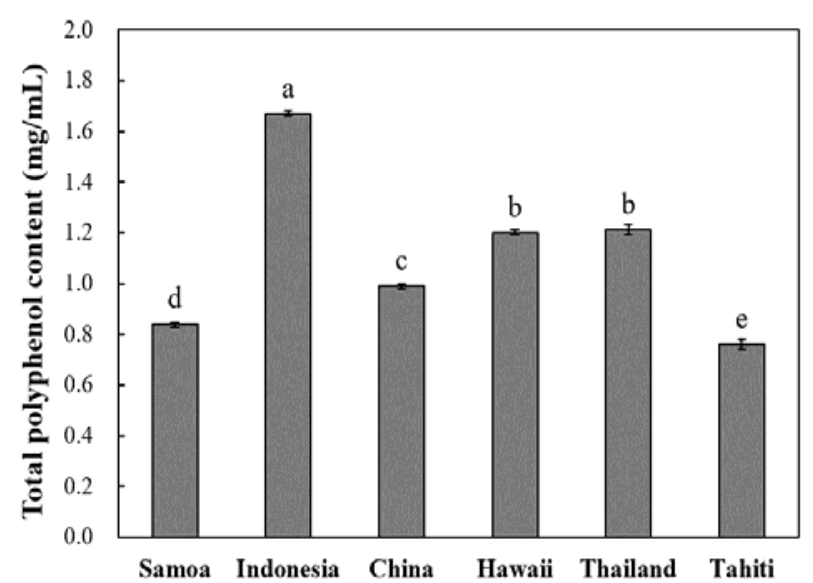

Fig. 1. Total polyphenol content of noni juices from different regions of cultivation.

Each bar represents the mean \pm SD of triplicates. Means with the same small letter in each bar are not significantly different at $\mathrm{p}<0.05$ using Duncan's multiple range test.

(22), 당근주스에 비해 노니 열매 착즙액의 폴리페놀 함량이 매우 높음을 알 수 있었다. 일반적으로 식물은 생산지별로 기후적 특성이나 토양적 특성 차이로 인해 같은 품종이더라 도 재배지역에 따라 내포하는 성분 차이를 보이며 특히 이차대사산물과 같은 특수성분의 함량은 큰 차이를 나타낸 다(23). 산지별 마늘의 인경과 잎의 폴리페놀 함량을 분석한 결과 인경, 잎 모두 산지에 따라 차이가 있었으며, 특히 잎 에탄올 추출물의 경우 울릉도 자연산 산마늘이 52.57 $\mathrm{mg} / \mathrm{g}$, 강릉 재배 산마늘 $10.98 \mathrm{mg} / \mathrm{g}$ 으로 약 4.8 배 차이를 나타낸다고 보고하였다(24). 뿐만 아니라 정읍, 순창, 횡성, 고창에서 수거한 복분자를 이용하여 제조한 복분자주의 폴리페놀 함량도 산지에 따라 차이를 나타내어(25), 본 연구 와 비슷한 경향을 보였다.

\section{산지별 노니 열매 착즙액의 스코폴레틴, 루틴 함량}

노니열매 주스에는 coumarins, flavonoids, phenolic acid, vanillin, iridoids 등의 화합물들이 존재하며, 특히 coumarins 계열의 스코폴레틴과 flavonoids 계열의 루틴은 노니 열매 의 핵심적 건강기능성 성분으로 알려져 있다(17). 따라서 본 연구에서는 산지별 노니 열매 착즙액의 스코폴레틴과 루틴의 함량을 분석하였으며, 결과는 Table 2 와 같다. 노니 열매 착즙액의 스코폴레틴 함량의 경우, 태국산이 8.62 $\mathrm{mg} / 100 \mathrm{~mL}$ 로 유의적으로 가장 높은 함량을 보였으며, 다음 으로 사모아산이 $6.22 \mathrm{mg} / 100 \mathrm{~mL}$ 로 높은 함량을 보였다. 반면 하와이산이 $2.76 \mathrm{mg} / 100 \mathrm{~mL}$ 로 가장 낮은 값을 나타내 었으며, 중국산이 $2.82 \mathrm{mg} / 100 \mathrm{~mL}$ 으로 두 번째로 낮은 값을 나타내었으며, 하와이산과 중국산은 유의적인 차이는 발견 되지 않았다. 타히티, 프랑스령 폴리네시아의 무레아섬, 통 가, 도미니카, 오키나와, 태국 및 하와이에서 재배된 노니열 매 메탄올 추출물의 스코폴레틴 함량은 각각 $0.66,0.76$,
$1.18,0.064,6.87,3.59,0.70 \mathrm{mg} / \mathrm{g}$ 으로 생산된 산지에 따라 다르게 나타났으며(8), 이러한 결과는 본 연구와 유사하였 다. 아시아를 포함한 다양한 나라에서 상업적으로 시판되 고 있는 노니주스 13종의 스코폴레틴 함량을 분석한 결과 (8), 주스 $100 \mathrm{~mL}$ 에 0.88-34.01 $\mathrm{\mu g}$ 을 함유하였으며, 살구주 스에 함유된 스코폴레틴 함량은 $0.03-0.07 \mathrm{mg} / \mathrm{L}$ 의 값을 보 여(26) 본 연구에서 분석한 노니 열매 착즙액보다는 다소 낮은 함량을 보였다.

6곳의 산지에서 수확된 노니 열매 착즙액의 루틴의 함량 은 0.45-2.03 mg/100 mL의 범위로 산지에 따라 유의적인 함량 차이가 보였다. 루틴 함량 역시 스코폴레틴 함량이 높게 측정되었던 태국산이 가장 높은 값 $(2.03 \mathrm{mg} / 100 \mathrm{~mL})$ 을 나타내었으며, 이는 타히티산보다 약 4.5 배 이상 높은 함량이였다. 포도주스에 포함된 루틴은 $3.261 \mathrm{mg} / \mathrm{mL}$ 로(27) 본 연구 결과보다 다소 높은 함량을 보였으며, 반면 아스파 라거스 주스의 루틴 함량은 253-273 $\mu \mathrm{M}$ 로(28) 본 연구 결과 보다 다소 낮은 함량을 보였다. 또한, Deng 등(8)의 전 세계 적 노니열매와 노니열매 가공품의 식물성 성분의 정량적 비교 연구에서 노니 열매 추출물의 루틴 함량은 산지에 따라 큰 폭으로 함량차이를 보였으며, 이는 본 연구의 결과 와 유사한 경향을 나타내었다. 따라서 노니 열매 착즙액의 생리활성물질인 스코폴레틴과 루틴의 함량은 산지별로 다 른 경향을 보였으며 이는 토양, 일광, 온도, 습기, 공기 등과 같은 지리적요인과 기후 및 환경적 요인 등에 영향을 받은 것으로 판단된다.

Table 2. Scopoletin and rutin contents of noni juices from different regions of cultivation

\begin{tabular}{ccc}
\hline Sample & Scopoletin $(\mathrm{mg} / 100 \mathrm{~mL})$ & Rutin $(\mathrm{mg} / 100 \mathrm{~mL})$ \\
\hline Samoa & $\left.6.22 \pm 0.08^{1) \mathrm{b} 2}\right)$ & $1.00 \pm 0.02^{\mathrm{c}}$ \\
Indonesia & $5.23 \pm 0.02^{\mathrm{c}}$ & $1.16 \pm 0.02^{\mathrm{b}}$ \\
China & $2.82 \pm 0.18^{\mathrm{e}}$ & $0.77 \pm 0.18^{\mathrm{d}}$ \\
Hawaii & $2.76 \pm 0.06^{\mathrm{e}}$ & $0.93 \pm 0.02^{\mathrm{c}}$ \\
Thailand & $8.62 \pm 0.29^{\mathrm{a}}$ & $2.03 \pm 0.08^{\mathrm{a}}$ \\
Tahiti & $3.70 \pm 0.07^{\mathrm{d}}$ & $0.45 \pm 0.02^{\mathrm{e}}$ \\
\hline
\end{tabular}

${ }^{1)}$ Each value represents the mean \pm SD $\quad(n=3)$.

${ }^{2)}$ Values in the column with different superscript letters are significantly different at $\mathrm{p}<0.05$.

\section{산지별 노니 열매 착즙액의 항산화 활성}

산지별 노니 열매 착즙액의 항산화 활성을 확인하기 위 하여 $\mathrm{DPPH}$ 와 ABTS 라디칼 소거능 효과를 측정하였으며, 결과는 Fig. 2와 같다. DPPH 라디칼은 항산화 물질의 전자 공여능으로 인해 라디칼이 소거되어 원래의 짙은 보라색이 탈색되는 정도를 흡광도로 측정함으로서 항산화능을 측정 
하는데 널리 사용되고 있는 방법이다. 산지별 노니 열매 착즙액의 DPPH 라디칼 소거능을 측정한 결과, 인도네시아 산이 $62.49 \%$ 로 가장 높았으며, 하와이산 $60.70 \%$, 타히티산 $60.59 \%$ 및 태국산 $60.51 \%$ 로 유사한 소거능을 나타내었으 며, 사모아산이 $58.46 \%$ 의 소거능을 나타내었고, 중국산이 $52.83 \%$ 로 가장 낮은 소거능을 보였다. Wang 등(29)은 lactic acid bacteria 및 bifidobacteria로 발효시킨 노니주스의 $\mathrm{DPPH}$ 라디칼 소거능을 측정하였으며, 그 결과 58.4-72.2\% 범위의 소거능을 나타내어 본 연구 결과에 비해 높은 값을 보였다. 또한 Cho 등(30)의 시판 천연 과일주스와 채소주스 의 항산화능과 임파구 DNA 손상 방지 효능 비교에 관한 연구에서 명일엽 녹즙, 토마토 주스, 당근주스, 오렌지 주스 가 각각 $11.2,16.4,19.1,37.0 \%$ 의 DPPH 라디칼 소거활성을 나타내어, 본 연구 결과에 비해 다소 낮은 활성을 보였다.

노니 열매 착즙액의 $\mathrm{ABTS}$ 라디칼 소거능을 측정한 결과, 모든 시료에서 $80 \%$ 이상의 라디칼 소거능을 나타내어 비교 적 매우 높은 항산화능을 보였다. 인도네시아산, 하와이산, 타히티산, 사모아산 노니 열매 착즙액의 라이칼 소거능이 $89.04,88.87,88.63,87.02 \%$ 로 높은 항산화 활성을 나타냈 고, 그 밖에 중국산과 태국산 각각 $84.20,81.08 \%$ 의 라디칼 소거능을 나타내었다.

따라서 산지별 노니 열매 착즙액 중 인도네시아산이 가 장 높은 라디칼 소거능을 나타내었으며, 이는 항산화성과 밀접한 관계가 있는 페놀 물질과 상관관계가 있기 때문인 것으로 생각된다. 그러나 인도네시아산을 제외한 나머지 산지별 노니 열매 착즙액의 페놀성 화합물과 항산화 활성 간에 뚜렷한 상관관계는 발견되지 않았다. 이는 항산화 활 성은 평가방법에 따라 효과가 상이하며, 총 페놀 함량뿐만 아니라 시료에 함유된 다양한 생리활성물질의 여부와 함량 에 따라서도 다르게 나타나기 때문으로 생각된다(31).

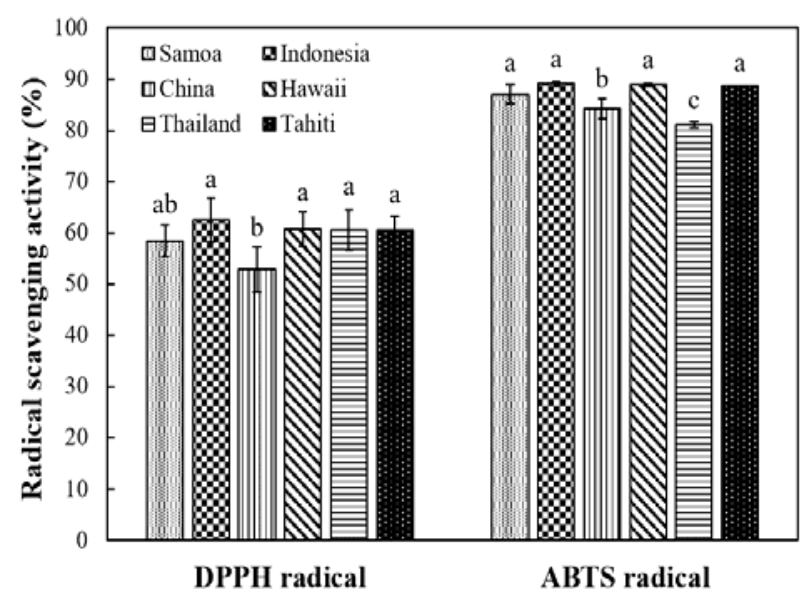

Fig. 2. Antioxidant activities of juices from different regions of cultivation.

Each bar represents the mean \pm SD of triplicates. Means with the same small letter in each bar are not significantly different at $p<0.05$ using Duncan's multiple range test.

\section{요 약}

노니의 주요 산지인 사모아, 인도네시아, 중국(하이난), 하와이, 태국, 타히티에서 생산된 노니 열매를 착즙하여 산지별 노니열매 착즙액의 이화학적 특성, 기능성 성분 및 항산화 활성을 비교분석하였다. 산지별 노니열매 착즙액의 $\mathrm{pH}$ 는 3.63-3.83 수준으로 나타났으며, 색도는 태국산이 다 른 산지 노니열매 착즙액보다 $\mathrm{L}, \mathrm{a}, \mathrm{b}$ 값 모두 유의적으로 낮은 값으로 나타났다. 고형분 함량은 5.97-6.97 ${ }^{\circ} \mathrm{Brix}$ 범위 로 하와이산이 $6.97{ }^{\circ} \mathrm{Brix}$ 로 가장 높았으며, 반면 인도네시 아산이 $5.97{ }^{\circ} \mathrm{Brix}$ 로 가장 낮은 값을 나타내었다. 태국산이 가장 많은 스코폴레틴과 루틴을 함유하고 있었으며, 인도 네시아산이 다른 지역에서 생산된 노니열매 착즙액보다 폴리페놀 함량이 유의적으로 가장 높았다. 항산화 활성 중 $\mathrm{DPPH}$ 라디칼 소거능은 인도네시아 > 하와이 > 타히티 > 태국 > 사모아 > 중국 순으로 나타났으며, ABTS 라디칼 소거능은 인도네시아 > 하와이 > 타히티 > 사모아 > 중국 $>$ 태국 순으로 나타나 인도네시아산이 가장 높은 항산화능 을 보였다. 이상의 결과, 태국산이 스코폴레틴과 루틴의 함량이 가장 높았으며, 반면 인도네시아산이 가장 우수한 항산화 활성을 가지는 것을 확인하였다.

\section{감사의 글}

이 논문은 중소기업벤처부에서 시행한 WC300프로젝트 기술개발지원사업(S2435140)의 재원을 지원받아 수행된 연구입니다.

\section{References}

1. European Commission-Scientific Committee of Food (2002) Opinion of the Scientific Committee on Food of Tahitian Noni ${ }^{\circledR}$ Juice. SCF/CS/DOS/18 ADD 2 Final, Brussels, Belgium, p 1-13

2. Lee JN, Kim SW, Yoo YK, Lee GT, Lee KK (2006) Anti-wrinkle effect of Morinda citrifolia (Noni) extracts. J Soc Cosmet Scientists Korea, 32, 227-231

3. Levand O, Larson HO (1979) Some chemical constituents of Morinda citrifolia. Planta Med, 36, 186-187

4. Lee HH, Yin LJ, Tai HM, Jiang ST (2016) Facilitating the release of bionutrients from Morinda citrifolia (noni) by cellulase hydrolysis and lactic acid bacteria fermentation and their effects on a-amylase and a -glucosidase activities. J Mar Sci Technol, 24, 648-655

5. Ikeda R, Wada M, Nishigaki T, Nakashima K (2009) 
Quantification of coumarin derivatives in Noni (Morinda citrifolia) and their contribution of quenching effect on reactive oxygen species. Food Chem, 113, 1169-1172

6. Chan-Blanco Y, Vaillant F, Perez AM, Reynes M, Brillouet JM, Brat P (2006) The noni fruit (Morinda citrifolia L.): A review of agricultural research, nutritional and therapeutic properties. J Food Compos Anal, 19, 645-654

7. Ulloa JA, Tapia NTG, Ulloa PR, Ramirez JCR, Rangel BEU (2015) Effect of soaking in noni (Morinda citrifolia) juice on the microbiological and color behavior of Haden minimally processed mango. J Food Sci Tech, 52, 3079-3085

8. Deng S, West BJ, Jensen CJ (2010) A quantitative comparison of phytochemical components in global noni fruits and their commercial products. Food Chem, 122, 267-270

9. Pawlus AD, Kinghorn AD (2007) Review of the ethnobotany, chemistry, biological activity and safety of the botanical dietary supplement Morinda citrifolia (noni). J Pharm Pharmacol, 59, 1587-1609

10. Wang MY, Su C (2001) Cancer preventive effect of Morinda citrifolia (Noni). Ann N Y Acad Sci. 952, 161-168

11. Yoo JS, Hwang JT, Yoo ES, Cheun BS (2004) Study on herbal extract on the Noni (Morinda citriforia). Korea J Biotechnol Bioeng, 19, 110-112

12. Bartsch H, Nair J (2000) New DNA-based biomarkers for oxidative stress and cancer chemoprevention studies. Eur J Cancer, 36, 1229-1234

13. Deng S, West BJ, Jensen CJ (2010) A quantitative comparison of phytochemical components in global noni fruits and their commercial products. Food chem, 122, 267-270

14. Folin O, Denis W (1912) On phosphotungsticphosphomolybdic compounds as color reagents. J Biol Chem, 12, 239-243

15. Blois ML (1958) Antioxidant determinations by the use of a stable free radical. Nature, 181, 1199-1200

16. Re R, Pellegrini N, Proteggenete A, Pannala A, Yang M, Rice-Evans C (1999) Antioxidant activity applying an improved ABTS radical cation decolorization assay. Free Radic Biol Med, 26, 1231-1237

17. Dussossoy E, Brat P, Bony E, Boudard F, Poucheret P, Mertz C, Giaimis J, Michel A (2011) Characterization, anti-oxidative and anti-inflammatory effects of Costa Rican noni juice (Morinda citrifolia L.). J Ethnopharmacol, $133,108-115$
18. Kim EM (2011) Formulation and Quality Characteristics of Noni Beverages Mixed with Red Ginseng, Rubus Coreanus and Pomegranate Extracts. Korea J Culinary Res, 17, 259-269

19. Burin VM, Falcao LD, Gonzaga LV, Fett R, Rosier JP, Bordignon-Luiz MT (2010) Colour, phenolic content and antioxidant activity of grape juice. Food Sci and Technol. 30, 1027-1032

20. Lu Y, Foo LY (2000) Antioxidant and radical scavenging activities of polyphenols from apple pomace. Food chem. $68,81-85$

21. Lin YL, Chang YY, Yang DJ, Tzang BS, Chen YC (2013) Beneficial effects of noni (Morinda citrifolia L.) juice on livers of high-fat dietary hamsters. Food chem, 140, 31-38

22. Son MJ, Son SJ, Lee SP (2008) Physicochemical properties of carrot juice containing Phellinus linteus extract and beet extract fermented by Leuconostoc mesenteroides SM. J Korean Soc Food Sci Nutr, 37, 798-804

23. Kang MH, Oh MK, Bang JK, Kim DH, Kang CH, Lee BH (2000) Varietal difference of lignan contents and fatty acids composition in Korean sesame cultivars. Korean J Crop Sci, 45, 203-206

24. Chang JP, Doh ES, Kil KJ, Yang JK, Yun CW, Lee GH, Jung YH, Ji YS, Kim BR, Choi MS (2011) Antioxidative activity of A.victorialis var. platyphyllum extracts. J Korean For Soc, 100, 408-416

25. Lee SJ, Ahn B. (2009) Changes in physicochemical characteristics of black raspberry wines from different regions during fermentation. Korean J Food Sci Technol, 41, 662-667

26. Fernandez de Simon B, Perez-Ilzarbe J, Hernandez T, Gomez-Cordoves C, Estrella I (1992) Importance of phenolic compounds for the characterization of fruit juices. J Agric Food Chem, 40, 1531-1535

27. Wu T, Guan Y, Ye J (2007) Determination of flavonoids and ascorbic acid in grapefruit peel and juice by capillary electrophoresis with electrochemical detection. Food Chem, 100, 1573-1579

28. Sun T, Tang J, Powers JR (2005) Effect of pectolytic enzyme preparations on the phenolic composition and antioxidant activity of asparagus juice. J Agric Food Chem, 53, 42-48

29. Wang CY, Ng CC, Su H, Tzeng WS, Shyu YT (2009) Probiotic potential of noni juice fermented with lactic acid bacteria and bifidobacteria. Int J Food Sci Nutr, 60, 
98-106

30. Cho M, Lee HJ, Kang MH, Min H (2017) Comparison of antioxidant activity and prevention of lymphocyte DNA damage by fruit and vegetable juices marketed in
Korea. J Nutr Health, 50, 1-9

31. Dasgupta N, De B (2007) Antioxidant activity of some leafy vegetables of India: A comparative study. Food Chem, 101, 471-474 